\title{
Addendum
}

\section{Synthesis of Halogenated Carboxylic Acids and Amino Acids}

Constantin Czekelius, * Carl Christoph Tzschucke* Synthesis 2010, 543.

Inadvertently, we failed to include the contribution of Rios, Moyano et al. on the organocatalytic conjugate addition of fluorobis(phenylsulfonyl) methane and fluoromalonate to unsaturated aldehydes ${ }^{1,2}$ and only cited an independent subsequent publication by Cordova et al. ${ }^{3}$ We are very grateful to Dr. Ramon Rios for bringing this omission to our attention and would like to apologize for this unintentional oversight.

(1) Companyo, X.; Hejnova, M.; Kamlar, M.; Vesely, J.; Moyano, A.; Rios, R. Tetrahedron Lett. $2009,50,5021$.

(2) Alba, A.-N.; Companyo, X.; Moyano, A.; Rios, R. Chem. Eur. J. 2009, 15, 7035.

(3) Ullah, F.; Zhao, G.-L.; Deiana, L.; Zhu, M.; Dziedzic, P.; Ibrahem, I.; Hammar, P.; Sun, J.; Córdova, A. Chem. Eur. J. 2009, 15, 10013. 